\title{
Background Activities in the Planning of a New Library
}

By ESTHER GREENE

$T_{1}$ he Adele Lehman Hall-Wollman Library is the first new building on the Barnard Campus in over thirty years. A building on a college campus in a city such as New York where each square inch of ground is hallowed is faced with many obstacles before it sees the light of day. A mere open space, to say nothing of trees and shrubbery, though of doubtful lineage, looms in the eyes and affection of some of the college community and its alumnae as possessing values not easily outweighed by a library of even the world's greatest thinkers. That Barnard dedicated its new library-classroom building on April 5 is evidence of the final decision of the trustees that new library facilities were essential for the continued educational growth of the college.

Barnard, although it is the women's undergraduate college of Columbia University, has its own board of trustees, faculty, and financial resources. The library too is separate, with its own book collection, administration, and staff. Its 75,000 volumes have been chosen over the years to meet the basic requirements of the college curriculum. Barnard's charter, however, grants to both its students and faculty free access to all the library resources of the university. This is a cherished privilege at Barnard and in book selection has permitted concentration on students' needs rather than developing library resources for faculty research.

The library was housed on the third floor of Barnard Hall in quarters built for it in 1918. Lack of space for its book collection and its readers, as well as limited opportunities for good service, had become of increasing concern. This con-
Miss Greene is Librarian, Barnard College.

cern was formulated in a report, submitted by the librarian and endorsed by the faculty library committee to the president back in 1946, strongly urging that serious consideration be given to providing a new library building.

The library was not alone in its need for new or expanded quarters. The science departments too had outgrown both space and equipment facilities. Office space for faculty was at a premium, as well as classrooms.

The following year an architectural firm was commissioned to make a study of the over-all building requirements of the college essential for expansion from an enrollment of 1,200 to a possible 1,500 students. All departments were interviewed in detail but the resulting plan was too ambitious: an estimated ten million dollars for a building to be a combined library and science building.

Although these plans were shelved, a faculty committee on new buildings was appointed with the librarian as a member to work out a realistic building program for the college. The deliberations of this committee over a period of months placed the renovation of Milbank Hall, the main administrative and class room building which included the science departments, as of first importance. This renovation to be followed as funds were available for new quarters for the library and a new dormitory. During these discussions the possibility of providing space for the library within the renovated building was raised but there was sufficient support to the premise that 


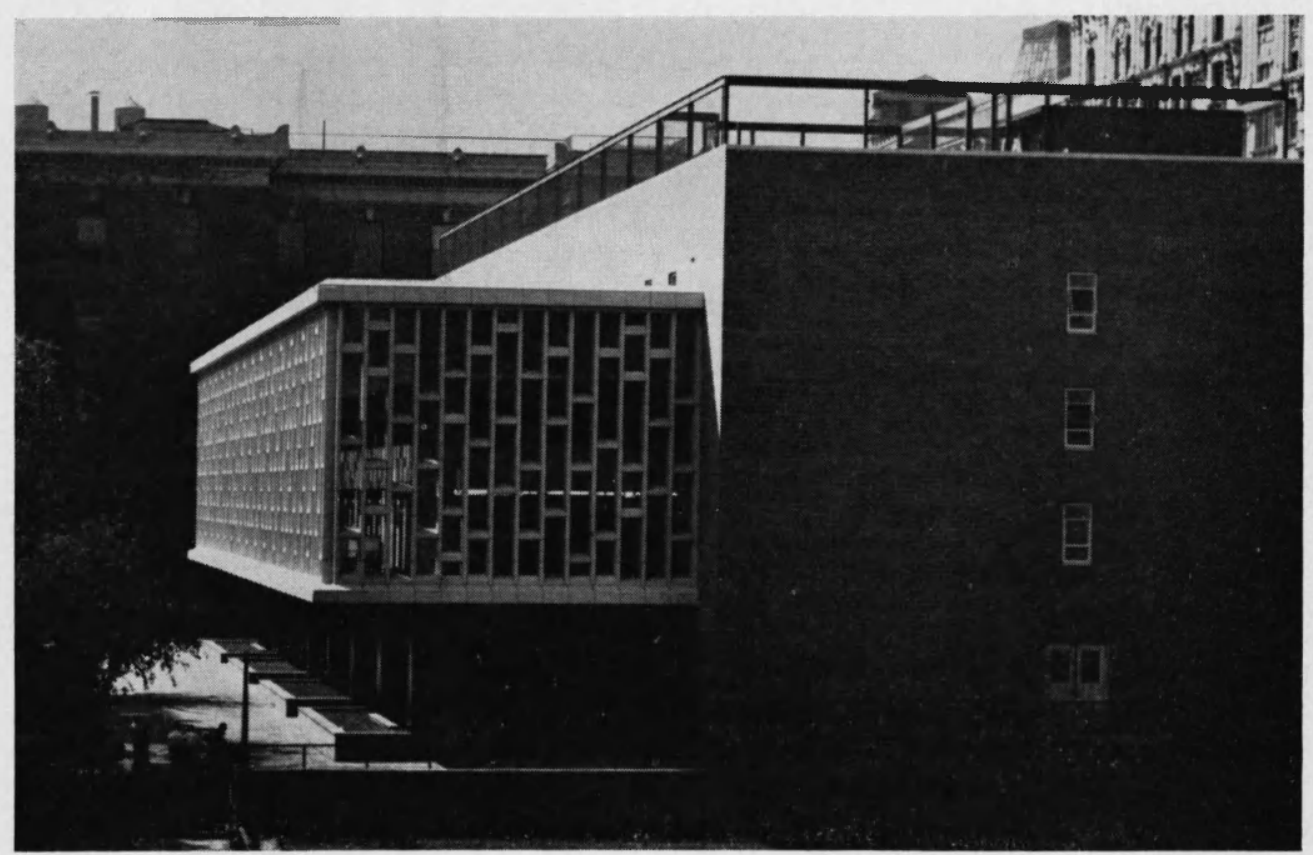

Adele Lehman Hall-Wollman Library

this was not the solution for the library.

Upon successful completion of the renovation another suggestion gained some support: that the library might attempt to expand around its present third-floor quarters, thus eliminating the need for an additional building which would consume coveted campus space. It was evident to those concerned with the importance of the library's place in the college program that the requirements for good library facilities to meet the needs of a vigorous expanding program must be given emphasis.

Professor Maurice F. Tauber, who is conversant with the University as well as with Barnard, was engaged to conduct a survey of Barnard's library facilities and to make recommendations. His recommendation that a new library building would best support Barnard's educational aims and was in fact essential was, after general faculty discussion, accepted by the trustees as the next item on Barnard's development program. The first spadeful of campus turf was about to be turned although the hours of committee meetings on plans for the new building had not as yet begun.

The architects were recalled and in conference with the buildings and grounds committees of both faculty and trustees the site was chosen. A new committee-the Ad Hoc Library Committee -of twelve members including the librarian-was appointed by the president and promptly set to work.

The librarian at once organized her staff into small groups to act as a committee of the whole. Considerations of this committee were carried on simultaneously with those of the policy-making ad hoc committee. An outline of topics on all aspects of library procedures as well as of basic equipment was formulated.

The reference librarian prepared from the last ten years of Library Literature a bibliography of references under each topic. These references were as- 
signed to the appropriate staff who, after reading the article, prepared a brief annotation of any pertinent article for the card file. The findings were discussed with the staff and over the reading period staff opinions were formulated on such possibilities as a divided catalog, subject divisional arrangement of the collection and services, smoking in the library, and carrells, to name but a few of the items considered.

Each professional member of the staff made one or more visits to new libraries. The ideas gained from seeing other libraries in operation and in discussing plans with their librarians added grist to the mill of our active file of ideas for the new building. For an account of each visit was likewise recorded on cards, with notations, for example, on such specific factors as width of aisles or the possibility of putting wheels on the tables used in the processing areas, the type of shelving best suited to recordings, etc.

The librarian attended two building conferences, one on college libraries and a series of meetings on public library buildings. Both were exceedingly helpful both in the specific programs presented and in the opportunity to show and discuss Barnard's plans with other librarians and building specialists. These activities helped to some degree the absence of a paid library consultant.

The ad hoc committee was the policymaking committee. It considered all phases of the library program as set forth by the librarian in her 5,000-word report of the requirements of a building best suited to carry on library functions at Barnard. Meetings were held almost weekly for nearly two years, with one or more of the architects usually in attendance. As soon as the program was accepted the committee turned its attention to specifications and equipment for the proposed building. Final decisions of major financial importance were made in committee meetings held jointly between members of the ad hoc committee and those of the Trustees Buildings and Grounds Committee.

During all of this period the librarian was also working directly with the architects as the layout of the building progressed. Close cooperation was realistically possible since the architects, O'Connor and Kilham, are a New York firm. The interrelationships of various functions carried on in the library by both staff and readers had been thoroughly discussed by the staff and incorporated in the librarian's program. From the very first drawings the architect incorporated these ideas into the general layout of each floor. As their plans were being developed the librarian, aided by her staff, furnished simple sketches of possible modifications and changes. Graph paper, architect's rulers, and paper mock-ups tested the abilities of certain staff members to think concretely about stack arrangements, circulation desk requirements, and such matters as the square footage required for each microfilm reader. When the going seemed especially rough the architect's philosophy that "there is always a way" and his willingness to find it no matter how small the problem gave constant encouragement.

Democratic procedures at Barnard provide for a number of committees, both faculty and student, to take part in discussion of most issues. The Development Committee, both faculty and student, had suggestions for the ad hoc committee.

One suggestion of major importance that came after tentative plans were well under way was that of combining classroom facilities and some faculty offices with the library by adding another floor - the addition in no way to interfere with the entity of the library. Here again campus space influenced the trustees' acceptance of this revised conception of additional college facilities. New sets of plans were made which met the approval of the ad hoc committee. In the spring 
of 1958, on a wet April day, a silver spade actually turned that anticipated shovelful of earth and the paper work and discussion of the past months began to take visible form.

The major responsibilities of the ad hoc committee were now at an end. Its place was taken by a small coordinating committee, composed of the chairman of the Trustees Buildings and Grounds Committee, the comptroller, the director of the development program, the chairman of the Faculty Library Committee, and the librarian. This committee worked directly with the architect on problems as they arose.

And what of the final results? Inherent in all the planning was the desire to erect a library building that would best carry out the educational program of the college and would, as well, permit Barnard to offer to the university community its due share of library facilities and services with a greatly expanded book collection. This brief summary of the way one college proceeded in a new building program is not the place to describe the building in detail, its floor plans and equipment, although the temptation is great. For the dramatic glass and terra cotta façade through which the soft colors of the interior are clearly visible has given this building architectural distinction as well as providing what both staff and library users believe is excellent functional arrangement.

The building has four stories and a ground floor. With 43,680 square feet on four floors devoted exclusively to library activities, the library is a self-contained unit within Lehman Hall. There is no traffic through the library on any floor for any other area of the building. The arrangement throughout this open-shelf library is flexible; books and readers are intermingled in all areas with pleasant working space adjacent in a number of small units to the sections of book shelving. Shelving is provided for 150,000 volumes. Seventy-five of the 590 seats are at individual carrells located in attractive areas adjacent to windows.

The first campus-level floor, set back from the loggia, smaller than the next two floors, is given over to reserve books. Two-thirds of Barnard students are commuters and this area offers study space at tables for two or four as well as openshelf reserve facilities. This floor also contains two loud studies, a typing room, a seminar room, and the staff lounge.

The second floor contains the main circulation desk, the reference collection, the periodical area, the main catalog, the literature collection, the processing room, a reference work room, the librarian's office, a treasure room, loud study and typing rooms. Both the first and second floors have attractive informal lounge areas.

The third floor houses the rest of the collection, has an audio-visual room with an adjoining equipment room, a fine arts print room, and listening facilities in an open area for thirty-two students using ear phones. Smoking is permitted in designated areas on each floor. One of the two elevators is restricted to staff use.

All of the equipment in the library is new-much of it is custom designed. Chairs, for instance, were chosen after many samples both commercial and of special design were displayed for student reactions. Color of walls, floor coverings, and fabrics used in special areas were chosen in consultation with the interior decorator member of the architectural firm.

The ground floor provides a receiving room for library gifts and a storage area for duplicate copies. There is also a well equipped room for library supplies. A language laboratory under the jurisdiction of the language departments is proving very popular. Three faculty offices, four seminar rooms, and the mechanical equipment for the building comprise the remaining space on this floor.

The top floor, set back as is the campus level floor, has brought together the so- 
cial science departments with five seminar rooms and seventeen faculty offices, making a fine working unit.

Classrooms and offices both on the fourth and ground floors are reached directly from the lobby with, as has been stated earlier, no traffic through the library. This combination library and classroom building has given Barnard an active center for intellectual activities. A library, classrooms, and faculty offices when well planned so as not to interfere with the smooth running of one another's activities can exist, we are finding, very happily within the framework of one building.

\section{Building Data}

\section{Architects:}

R. B. O'Connor and W. H. Kilham, Jr.

\section{Project cost:}

$\$ 2,200,000$.

\section{Building cost:}

$\$ 1,820,000$.

Number of stories:

4 stories and ground floor.

Over-all dimensions:

$185^{\prime}-6^{\prime \prime}$ long x 86'-6" wide.

Modular column spacing:

$22^{\prime}-6^{\prime \prime} \times 24^{\prime}-8^{\prime \prime}$.

\section{Gross areas:}

Library

Classrooms, offices, and other

Total enclosed space

Campus arcade

Rooftop recreational courts

\section{Cubic footage:}

Building

Campus arcade

Book capacity:

150,000 volumes.

5,700 sq. ft.

7,100 sq. ft.

83,000 cu. ft. $70,300 \mathrm{cu} . \mathrm{ft}$.
Library seating:

566 , not including staff service areas.

Exterior walls:

Masonry cavity wall with brick facing.

Terra cotta trims.

Terra cotta and glass front:

$170^{\prime}-6^{\prime \prime} \times 24^{\prime}$.

Exterior columns:

Covered with mat-glazed turquoise terra cotta.

Planting boxes and benches:

Brick and bluestone.

43,680 sq. ft. Interior walls:

22,640 sq. ft. Plastered gypsum block partitions painted.

Facing of birch panel in some locations.

Floors:

Vinyl-asbestos tile, in general.

Ceramic tile in toilet rooms.

Bluestone flagging in lobby arcade and on terrace.

Carpeting in treasure room, Gildersleeve area, and librarian's office. 
Ceiling:

Fiberglas acoustical tile, in general.

\section{Illumination:}

Mostly fluorescent.

Incandescent in some reading areas.

\section{Ventilation:}

Mechanical ventilation system providing circulation of tempered, filtered, and humidity-controlled air throughout building and through stack aisles.

Provisions made for future air-conditioning.

\section{Heating:}

Forced hot water convector system. Zoned, automatic temperature control.

\section{Furniture:}

Library:

- Mostly custom-built furniture in cherry and birch, designed by O'Connor and Kilham: 464 chairs (backs of two-thirds of the chairs upholstered in 6 colors of Naugahyde): 51 carrells of birch, plexiglass, and woven cane; 24 individual birch desks for students.

Birch circulation desks, card catalog, book trucks, exhibit cases, metal stacks with birch ends, and free-standing wooden shelves by Remington Rand.

Steel furniture by All Steel Equipment and by Steelcase.

\section{Departmental Classrooms:}

Seminar tables and chairs-some with vinyl upholstered seats-sofas, lounge chairs, and other pieces by Thonet.

Armorply chalkboards, vinyl covered tackboards by U. S. Plywood.

\section{Curtains:}

Silk and linen curtains in the treasure room, Gildersleeve area, librarian's office, staff lounge, and departmental classrooms.

Special areas:

Library:

Virginia C. Gildersleeve reading area.

Listening area.

Periodical area (with informal lounge).

Reference area.

Reserve book area.

Smoking areas.

Special rooms:

Library:

Audio-visual room (accommodates 50 students).

Print room (contains 117 exhibit panels).

Treasure room.

Loud studies.

Seminar room.

Typing cubicles.

Staff offices, work rooms, and lounge.

\section{Classrooms:}

6 Social Science departmental classrooms

2 classrooms for general use.

20 offices.

The Lehman Language Laboratory (29 booths).

Economics statistical laboratory.

Sculptor:

Rhys Caparn.

\section{Color Consultant:}

Teresa Kilham.

Structural Consultant:

Throop and Feiden.

Mechanical Consultant:

James Mongitore Associates. 